\title{
A Spoonful Of Humor Helps The Lecture Go Down
}

James R. Henderson (E-mail: leahhenderson@comcast.net), University of Southern Mississippi

\begin{abstract}
The goal of every teacher is to connect with his or her audience. Humor has a way of disarming the listener and opening up lines of communication. The purpose of this paper is to give reasons for using, ways to incorporate and benefits of humor in the lecture. Laughter is not only the best medicine, but does not require a prescription.
\end{abstract}

\section{INTRODUCTION}

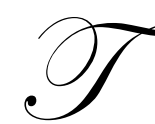

he noted scholar Cyndi Lauper once admonished the world that "girls just want to have fun". I think a thorough study of the concept of the idea would prove that not only girls, but guys also want to have fun. During the darkest hours of the Civil War Abraham Lincoln brought his cabinet together to read to them from a book of humor. Sensing their puzzlement, if not a lack of respect for his actions, he simply stated "Gentlemen, why don't you laugh? If I did not laugh I should die and you need this medicine as much as I do.”

At a recent Emmy tribute to Johnny Carson, David Letterman said that for four decades Johnny made us laugh, not only at ourselves, but at the difficult situations that existed in the world. According to Letterman, Johnny made us go to bed each night feeling a little better about our own day to day struggles.

\section{BENEFITS OF HUMOR}

Hospitals have found that humor has a healing and pain reducing effect on patients. Patients given the chance to self administer pain medicine with a simple use of a button used less if they were laughing or watching humorous videos. Dr. William Ivy has conducted laboratory studies that have shown that mirthful laughter affects most, it not all of the major physiological systems of the human body. He states that "twenty seconds of guffawing gives the heart the same workout as three minutes of hard rowing". Laughter has a cleansing effect on the body, removing harmful toxins and attitudes that germinate inside us and eventually will destroy us bit by bit.

It would appear that humor is healthy or, as they say "laughter is the best medicine". But that is not true for accountants. Accountants are conservative, if not negative humans who always recognize the bad while delaying any recognition of the good until absolutely forced. It is said that auditors have no sense of humor, no emotions, no heart and fortunately, no ability to reproduce resulting in their eventual extinction. If Lincoln thought humor was important during his trying times in office, then doesn't it stand to reason it is necessary in the difficult business world that exists today? Donald Trump, a somewhat successful entrepreneur, recently won national singing contest by recreating Eddie Albert's role in the well known duet theme song of the old Green Acres television show. Will this quite humorous attempt of Mr. Trump to delve into the musical world make him a weaker target in future board room negotiations? This writer is not inclined to think so.

The intent of this article is not to encourage every accountant to become Laurel and Hardy. It is simply not practical, nor could many accomplish the feat. But is it "relevant" for accountants to lighten up? Must accountants maintain the stiff, unanimated and boring image as seen and mocked on every award show (Miss America, the Oscars, Miss Universe, the Emmys, etc.)? 
In over thirty years of teaching and delivering seminars to businesses I have had four goals for every discussion I have led. These four goals were to have fun, to learn something, to complete the class or seminar and to have "warm fuzzies". Though most of these are easily understood the warm fuzzy point often gets a few puzzled looks. You know the feeling of a warm fuzzy if you have ever hit the perfect golf shot, connected with a baseball or softball with such exquisite timing that the ball didn't even seem to hit the bat, shot a three pointer with the assurance that there was no place that it could go but buried deep in the net or felt that first tug on the line that you know will produce the lunker of your dreams. It's a feeling that starts at the top of your head and permeates to your toes. It's a feeling that even though the world is full of turmoil and heartache, for that brief instant, all is well with your soul. I try to tell students that is the same feeling they will receive every time the balance sheet balances or a problem checks out - a warm fuzzy! When the "warm fuzzy" concept is explained, students often smile and then they catch themselves. Almost guiltily they think that they shouldn't be enjoying accounting and quickly wipe off their smiles and return to a more conservative, dull, accounting-hating perspective

But why should a goal of a class or seminar be fun? Is it so the students will like the professor? Is it because the instructor likes the students and therefore wants them to have fun? NO! The theory is simple, if the students have fun they will spend more time doing it and getting better at it. My wife enjoys completing crossword puzzles each night as we sit in the quiet of our home. I ask the students why she does this so often. The overwhelming response from the students has something to do with my inadequate conversational and social skills. That may be a contributing factor but the driving force behind her never ending crossword solving is because she likes to do them. They are fun! People have a tendency to do what is fun. How then do we make accounting more fun?

\section{MAKING THE LECTURE FUN}

The first step and perhaps the easiest and most rewarding is to start with a smile. Holiday Inn was looking for 500 employees for a new hotel. They conducted over 5000 interviews and eliminated the majority of the applicants for the lack of a smile. Those who were given follow up interviews smiled at least four times in the initial interview. Dr. John Diamond wrote in his book Your Body Doesn't Lie that "smiling helps strengthen the thymus gland, an important contributor to a healthy immune system". Most people believe that if someone yawns it is almost impossible to not yawn in return. I would challenge you to try to smile at others and see if it is not returned. Walking out of a department store, perhaps in deep thought about my next lecture, I was confronted by an elderly lady who asked why I looked so sad. She said "you're young and you look healthy, why aren't you smiling?" Feeling properly chastised and embarrassed, I apologized and promised to do better. Smiling will disarm others and strengthen your position in negotiating because people will always wonder what you know that they don't.

Smiling is one thing but how do we make a class more fun? One colleague wanted to increase his sense of humor rating as evaluated by the student questionnaires. To do this, he incorporated a joke a day into his lectures. His students would now feel cheated if he forgot to tell a joke. It is one time that you know they listen even thought it is not going to be on the test. The students have always thought of this professor as an excellent teacher and now consider him a budding humorist.

You are thinking "but I can't tell jokes". Some of the biggest laughs that Johnny Carson, Jay Leno and David Letterman ever received were not for funny jokes, but because of their reactions to jokes that failed miserably. One's ability to laugh at himself or not to take himself too seriously can be very funny and quite often charming. If the student realizes that the professor can laugh at himself, they are not so hesitant to ask questions that they fear others will consider too simple or stupid. Humor is relaxing and creates an atmosphere for openness and honesty which is beneficial for learning. I knew the students were grasping the concept when one student expounded in his student evaluation, which by the way was sent to my immediate boss, how he enjoyed the complimentary Kool Aid that I always served with my tests from hell. (This evaluation was written one semester after the Jonestown suicides.) This student understood that accounting may be difficult but there is no need to lose one's sense of humor.

How do we find humor? It's quite simple, you look for it! I tell students that if they are looking for accounting to be hard, dull and boring, it will be. I am reminded of the Native American who was walking down a busy New York City street with a friend. He stopped and asked, "Did you hear that cricket?" His friend replied that 
there were people talking, horns blowing, brakes squealing and jack hammers pounding. "You can't hear a cricket" his friend said. "But I can" he replied as he crossed the street and dug into a flower pot to reveal a cricket. His friend was amazed and said you Native Americans must have super human hearing. "No" he answered as he took a quarter from his pocket. He then dropped the coin to the sidewalk and it made the clinking sound we all recognize. It was as if someone said "E. F. Hutton says" because all the passersby on the crowded sidewalk turned to look. The Native American told his friend that too many people listen for money while he preferred to listen for birds, crickets and other sounds of nature. We need to train our students, not only to think "conservatively in accounting", but to be more pleasant to be around and to look for ways to make others smile.

But I can't tell a joke or make fun of me is the thought of many readers at this point. But you can post a joke or cartoon a day on your door. Students will come by just to see them and will even bring them to you in the future. This will naturally increase the communication lines between professor and student and will provide teaching and counseling moments that would not have otherwise been available. This writer is aware of one psychologist who filled her waiting room with Far Side books to put prospective patients at ease I personally copied this practice when serving as vice-president of a major university. My conversations with business people, staff, administrators and faculty always began more pleasantly and productively if my visitors had time to read at least a few pages of the warped humor of Far Side.

The main purpose of this paper has been to extol the benefits of humor in the classroom as a means of improving communications and making the learning process more enjoyable and profitable for the student. Perhaps the greatest benefit comes to the professor himself. Bill Murray at the end of the movie A Christmas Carol gave an impassioned discourse praising the benefits of doing good for others, not just at Christmas but all year long. He said that it gives you a feeling that you will crave and want twelve months of the year. This writer believes that humor provides a similar "warm fuzzy" to the professor that will make his life richer, fuller and more rewarding.

\section{CONCLUSION}

In closing, this writer would like to relate a personal experience shared with another professor. I was making a presentation to the entire student body of 3,500 at a former university and was using an overhead projector to help communicate with the audience. I had enlisted a fellow professor to handle the display of overheads in the center of the auditorium. The professor had been told to botch the job miserably which he accomplished admirably. After three failed attempts to properly place the overhead on the projector, I asked the audience if there was anyone who knew how to properly operate this machine. Previously I had asked another professor, affectionately known to the students as "Overhead Fred" because of his liberal use of overheads in his lectures, if he would be willing to operate the overhead projector for me. As I begged for help, Fred jumped to his feet and said he could operate the machine. As he made his way to the projector the student body began to applaud. As he grew closer, the noise grew louder. He dramatically removed the overhead and properly placed it as the audience rose to its feet in a thunderous roar. As Fred made his way back to his seat, I said thanks for manning the overhead, Fred. This was the first public use of this affectionate but quite private nickname. My fear of having offended him vanished when he approached me later in the week. He said he had received more recognition from that two minute presentation than he had from fifteen years of teaching. He and I went on to do numerous presentations in the future and my respect for him grew deeper.

As the commercial on TV states, we don't make the product, we make it better, stronger, prettier, brighter, etc. Humor doesn't make the professor; it makes him better, happier, more approachable and more fulfilled. I challenge each of you to try this simple action. The next time you complete a lecture, finish a difficult problem, or make a major point, turn to you students and say, "As James Brown would say 'I FEEL GOOD'." Then smile and enjoy the reactions of your listeners. 
NOTES 